\title{
The sexual behaviour of the pygmy newt, Triturus pygmaeus
}

\author{
J. Hidalgo-Vila, N. Pérez-Santigosa, C. Díaz-Paniagua ${ }^{1}$ \\ Estación Biológica de Doñana (CSIC), Apdo 1056, 41080 Sevilla, Spain \\ ${ }^{1}$ Corresponding author; e-mail: paniagua@cica.es
}

\begin{abstract}
The courtship behaviour of pygmy newts, Triturus pygmaeus, consists of three phases: orientation, static display (often not clearly differentiated from each other) and spermatophore transfer. The repertoire of male sexual behaviour consists of nine different movements. Exhibition, an alert posture in which the male advances with small jumps around the female, is the most frequent behaviour. The predominant tail movement is slow fan, in which the tail is softly undulated from approximately $30^{\circ}$ to $140^{\circ}$. In contrast to the tail lashes of the large Triturus species, the tail only occasionally beats against the male's flank and never touches the female. Bait mimic tail movements (described for T. boscai as flamenco) are used to attract the female's attention. The duration of sexual encounters was $2203 \mathrm{~s}$ on average, in which males displayed in about $81 \%$ of this time. Although the courtship of T. pygmaeus shows clear differences from that of its closest relative, T. marmoratus, it should nevertheless be grouped with the larger Triturus species: conspicuous tail movementes are used to attract the attention of the female, but no direct response is required of her to complete the courtship.
\end{abstract}

Resumen. En el cortejo de los tritones enanos, Triturus pygmaeus, se pueden distinguir tres fases diferentes: fase de orientación, fase de exhibición estática y fase de deposición del espermatóforo. Las dos primeras no se distinguen claramente, sino que frecuentemente se alternan entre sí. Los machos de esta especie realizan nueve pautas diferentes relacionadas con el comportamiento sexual. Entre ellas, destaca la que denominamos exhibición, en la que el macho, en una posición de alerta con todo su cuerpo muy estirado, realiza pequeños saltos alrededor de la hembra. Este comportamiento, que es el que se observa con mayor frecuencia, parece tener un papel importante como señal visual en el cortejo. Otra pauta importante por su frecuencia es la denominada abanico lento, en la que los machos ondulan lentamente su cola, a la vez que abren y cierran el ángulo (que oscila entre $30^{\circ}$ y $140^{\circ}$ ) que ésta forma con su cuerpo. Otra pauta característica es el latigazo corto, un movimiento brusco de la cola similar al de otras especies de tritones, de las que se diferencia porque la cola sólo ocasionalmente alcanza a golpearse contra su propio cuerpo y nunca llega a tocar a la hembra. Se describe en esta especie una pauta de engaño, flamenco, en la que los movimientos de la cola imitan a los de supuestas presas con el fin de atraer rápidamente la atención de la hembra. Esta pauta había sido descrita anteriormente para $T$. boscai. La duración media de los cortejos fue de $2203 \mathrm{~s}$, en los que el $81 \%$ de este tiempo los machos elaboran pautas de cortejo. Aunque el cortejo de T. pygmaeus muestra claras diferencias con la especie próxima, T. marmoratus, se considera que debe ser clasificado en el mismo grupo, entre los tritones de mayor tamaño, en las que el cortejo se caracteriza por el uso de comportamientos muy conspícuos para la atracción de la hembra, y en el que no se requiere un respuesta directa de la hembra para realizar la deposición del espermatóforo. 


\section{Introduction}

The species of the genus Triturus have internal fertilisation and complex courtship behaviour, in which contact between the male and female is minimal. Sexual behaviour has been described in detail for several species of Triturus (see e.g. Halliday, 1974, 1977, 1990; Arntzen and Sparreboom, 1989) and courtship encounters have a similar pattern for all. The male repertoire of activities includes tail and body movements that aim to attract the attention of the female and, ultimately, lead to the deposition of a spermatophore. In addition, some species are characterised by a marked sexual dimorphism with males showing large crests and conspicuous colouration, and these characters are thought to play an important role in sexual behaviour and mate choice (Halliday, 1974, 1975; Himstedt, 1979; Green, 1989). Courtship can be differentiated into three main phases: the orientation phase in which the male locates the female and attempts to attract her attention; the static display phase which consists of a series of more or less stereotyped movements performed by the male once the female is standing still; the spermatophore transfer phase during which the male deposits a spermatophore which the female may or may not pick up with her cloaca (Halliday, 1974, 1990).

Some authors have classified Triturus species into different phylogenetic groups using sexual characteristics (behaviour and morphology), as well as other genetic and taxonomic criteria (Giacoma and Balletto, 1988; Arntzen and Sparreboom, 1989). Halliday (1990) divided the genus into three groups; small species, large species and a third group containing only alpine newts (T. alpestris). Males of the small species (T. vulgaris, T. helveticus, T. italicus, T. boscai and T. montandoni), do not develop high crests (except for T. vulgaris), and include delicate tail movements in their courtship encounters which carry odour signals to the female. The males require a positive response by the female to complete courtship, and most species include an additional phase (retreat phase) to ensure that the female is responsive before beginning the spermatophore transfer phase. Males of the large species ( $T$. vittatus, $T$. cristatus and $T$. marmoratus), are characterized by high crests and conspicuous coloration, and include vigorous tail movements in their sexual display (although $T$. vulgaris also show these features). For these species, visual signals seem to be of prime importance during sexual interactions. Triturus alpestris has a much simpler courtship and is placed in a group of its own (Halliday, 1990). In this species, during the spermatophore transfer phase, the male either waits for a positive response of the female or exhibits luring tactics with unresponsive females (Denoël et al., 2001).

Previously considered a subspecies of T. marmoratus, the pygmy newt, Triturus pygmaeus (Wolterstorff, 1905), has recently been described as a new species (García-París et al., 2001). Triturus pygmaeus is smaller than T. marmoratus and has a lower dorsal crest, and the species has a similar (but distinguishable) colour pattern (García-París et al., 2001). Body size in T. pygmaeus varies widely throughout its range (García-París et al., 1993) and the newts from the study population in SW Spain are the smallest individuals of this species (Díaz-Paniagua et al., 1996). Adults from this population enter the ponds 
for breeding in autumn, and most courtships are observed in January, while oviposition is mainly located in February or early March, at the end of the aquatic annual period of adults (Díaz-Paniagua, 1998). The aim of this paper is to describe the courtship behaviour of the pygmy newt, and to compare it with the sexual behaviour of the marbled newt and other species of the genus.

\section{Materials and methods}

This study is based on observations of 177 newts (112 males and 65 females) collected from temporary ponds in Doñana National Park (SW Spain) from October 1999 to March 2000. Data from two additional courtships (two males and two females), recorded in January 2001, are included in order to increase the sample size of courtships containing spermatophore deposition.

Observations were recorded within 3-4 days of capture, in a laboratory located in the study area (about $2 \mathrm{~km}$ from the furthest pond). Males and females were housed separately, in aquaria provided with sand and aquatic plants from the pond and fed daily with earthworms. Water temperature was not controlled, and ranged from $14^{\circ}$ to $17^{\circ} \mathrm{C}$, following the natural daily cycle. Upon capture, all newts were measured, weighed, and individually identified by taking lateral and dorsal photographs of their colour patterns.

A total of 289 trials were observed in aquaria of $45 \times 60 \times 30 \mathrm{~cm}$ containing 301 of water. Sixty-six encounters contained courtship and were recorded on video. Of these, only 32 coutships were considered after discounting those of very short duration or those with repeated males. The male was introduced into the aquarium about half an hour earlier than the female, and the encounter was considered to have started when the first sexual behaviour was observed. Most sequences containing sexual encounters were recorded between 19:00 and 02:00 h.

For each courtship we recorded the time devoted to each behaviour by measuring the time taken until the behaviour was interrupted or changed to a different one. This is referred to as a behavioural bout. We also recorded the total number of times a behaviour was performed. The total duration of a courtship was considered to be the difference between the end and start times of the courtship encounter, while the time invested in male courtship was the sum of the time recorded for every male behavioural bout performed during the encounter. We constructed the first order transition matrix by counting the number of transitions from one male behaviour to another.

The mean duration of each behaviour was calculated per courtship. The duration of courtships including spermatophore deposition was compared with other courtships using analyses of variance (ANOVA).

\section{Results}

The repertoire of courtship behaviour

In describing the courtship behaviour of $T$. pygmaeus, we have defined nine courtship movements or acts performed by the male and five by the female. Some definitions are based on behaviours seen in the other Triturus species, while two behaviours are described for T. pygmaeus.

Male behaviour:

Sniff: The male approaches the female and presses his snout towards her vent, head, flank or tail. 
Exhibition: The male positions himself in front of the female by advancing rapidly with small jumps and short swimming bursts. He stops suddenly in front of her, maintaining a characteristic posture (standing on the tip of the toes, body and tail rigid and straight, head up, and limbs and crest extended) which provides a clear view of his conspicuous colouration (fig. 1a). This behaviour may be performed while advancing towards the female or moving around her, sometimes preventing her from moving forward and sometimes moving away from her.

Slow fan: A slow regular fanning movement of the tail. The distal half of the tail is held out at a wide angle of about $140^{\circ}$ to the flank and then closed softly to about $30^{\circ}$ in an undulating movement (fig. 1b). Only occasionally the folded tail closes the angle to a position parallel with the flank. The male often stops fanning with the tail forming an angle of approximately $90^{\circ}$, and remains static exhibiting the coloured flank and crest to the female. During slow fan, the abdomen is slightly curved up in the centre and the head held up. Males perform slow fan on the side facing the female.

Whip: A sudden lash of the tail. The tail is held out at an obtuse angle, and then suddenly launched against the flank of the body, producing a blast of water towards the female (and often pushing the male backwards). The tail of the male never touches the female's body or head. Whip frequently finishes with a characteristic posture in which the male holds the tail at an angle of about $140^{\circ}$, and this often leads to slow fan.

Creep: The male turns $90^{\circ}$ to $180^{\circ}$ so that he no longer faces the female, and walks two or three jerky steps in front of her, keeping his cloaca close to the ground. The cloaca is protruded, the base of the tail elevated, and the rest of the tail held parallel to the ground and slightly raised, sometimes extended, or sometimes s-shaped.

Quiver: After creep, the male stands with his back to the female, head raised, rubbing the ground with his protruded cloaca and moving the distal part of the s-shaped tail from side-to-side. The tail is then slowly and spasmodically raised.

Flamenco: The male is positioned with his back and tail towards the female, some distance away. He stands with head raised and limbs extended, raises his tail to between $45^{\circ}$ and $90^{\circ}$ and softly undulates the tip from side to side (fig. 1c). In this study, flamenco was usually performed at a distance of approximately $15-20 \mathrm{~cm}$ to the females, which in most cases were not responsive ( 16 out of $22, n=9$ courtship sequences).

Spermatophore deposition: Following an approach by the female (which usually bites or touches the tail of the male), the male suddenly raises the tail up to about $90^{\circ}$ and steps forward, extruding the spermatophore.

Wiggle tail bent: Immediately after spermatophore deposition, the male turns with two or three quick steps and stands perpendicular to the female, so that the spermatophore is positioned between the partners. The s-shaped tail is folded against his flank, and the 
a)

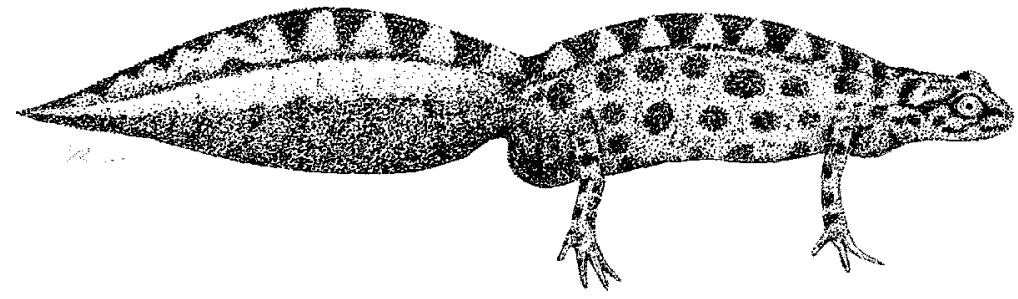

b)

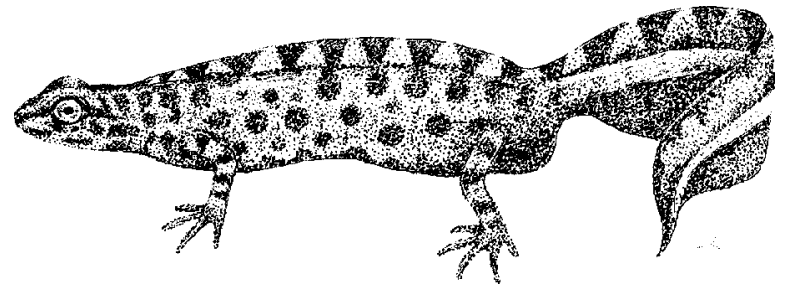

c)
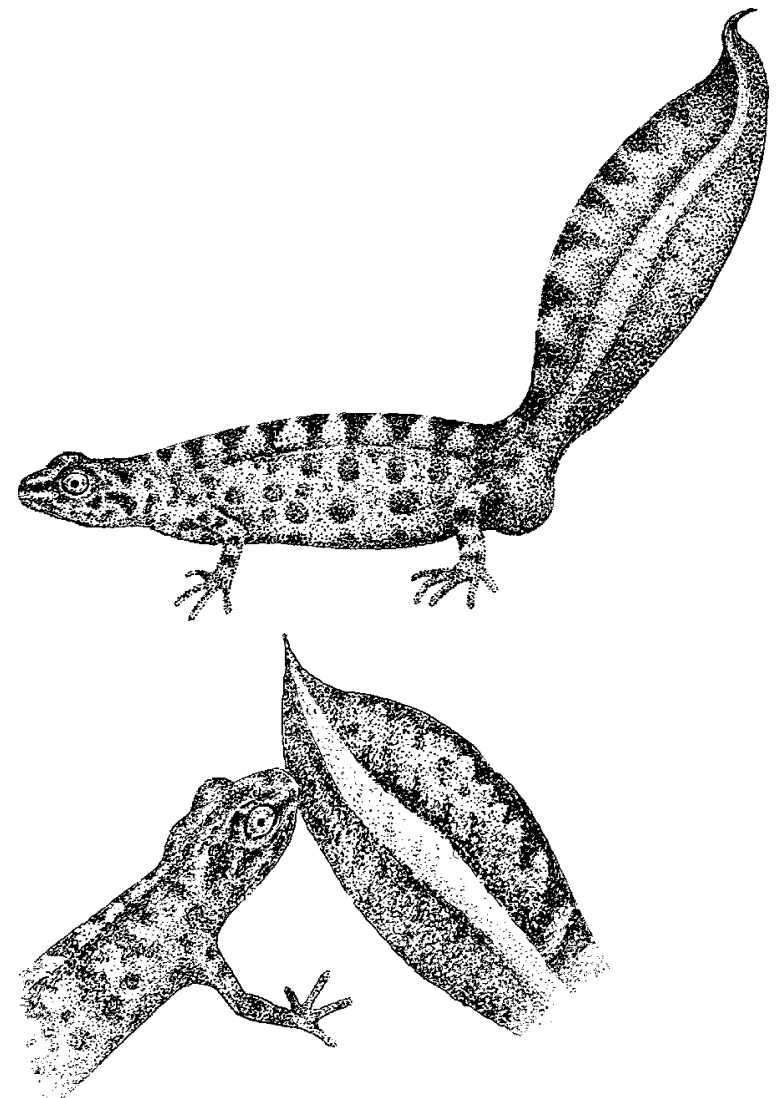

d)

Figure 1. Four different behaviours of the sexual encounter in T. pygmaeus. a) Exhibition; b) Slow Fan; c) Flamenco; d) a female touching the tail of a male after flamenco. 
most distal part is slightly elevated, making worm-like waving movements. As the female advances towards the moving tip of the tail, the male extends the waving tip of the tail, as if pointing to the spermatophore.

Female behaviour:

Attention: A female may be considered responsive or showing attention to a male when she is standing stationary and facing the male (usually with head raised). In any other case, she may be considered unresponsive, showing no attention to a male.

Sniff: The female behaves in the same way as described for the male.

Slow fan: The female occasionally performs slow fan in a similar way to the male, with the tail slightly folded or even forming an angle $<10^{\circ}$ with the body. She is usually some distance away from the male.

Tail touch: During quiver or flamenco, the female may be attracted by the movements of the tip of the male's tail. She approaches the moving tail tip slowly, with head raised. As the male slowly raises his tail to a perpendicular position (prior to spermatophore deposition), the female touches the lower part of the male's tail with her snout (fig. 1d).

Spermatophorepick up: During wiggle tail bent, the female again approaches the moving tail tip of the male. As the male steps backwards slightly, the female continues to approach until she touches his flank or tail with her snout. As she approaches, the female steps over the spermatophore, which may or may not adhere to her cloaca.

\section{Temporal organisation of the sexual encounter}

Courtships usually start with male exhibition, in the Orientation Phase, during which the female is unresponsive. If the female moves away from the male, or simply moves forward without looking at him, the male will continue with exhibition, abruptly moving around the female, either close by or at a distance but always exhibiting a wide lateral view to her. Exhibition is frequently alternated during this phase with slow fan (fig. 2), in which the male is positioned near the female (often perpendicular to her), trying to block her way. The male folds his tail towards the side of the female and fans slowly, producing a smooth current of water. Sniff is occasionally performed during this phase. Once the female is showing attention (usually stationary or moving only in short steps), the male positions himself nearby (but not touching) and continues with slow fan, whip, and exhibition for a considerable time (fig. 2). This is the Static Display Phase. In this study, 62\% of courtships started with Orientation. In the remaining 38\%, females were responsive from the start and courtships began with static display.

The third phase, Spermatophore Transfer, begins when the male turns away from the apparently responsive female into creep. We observed creep in 12 out of 32 (38\%) courtships, but the males completed this phase with spermatophore deposition in six cases 


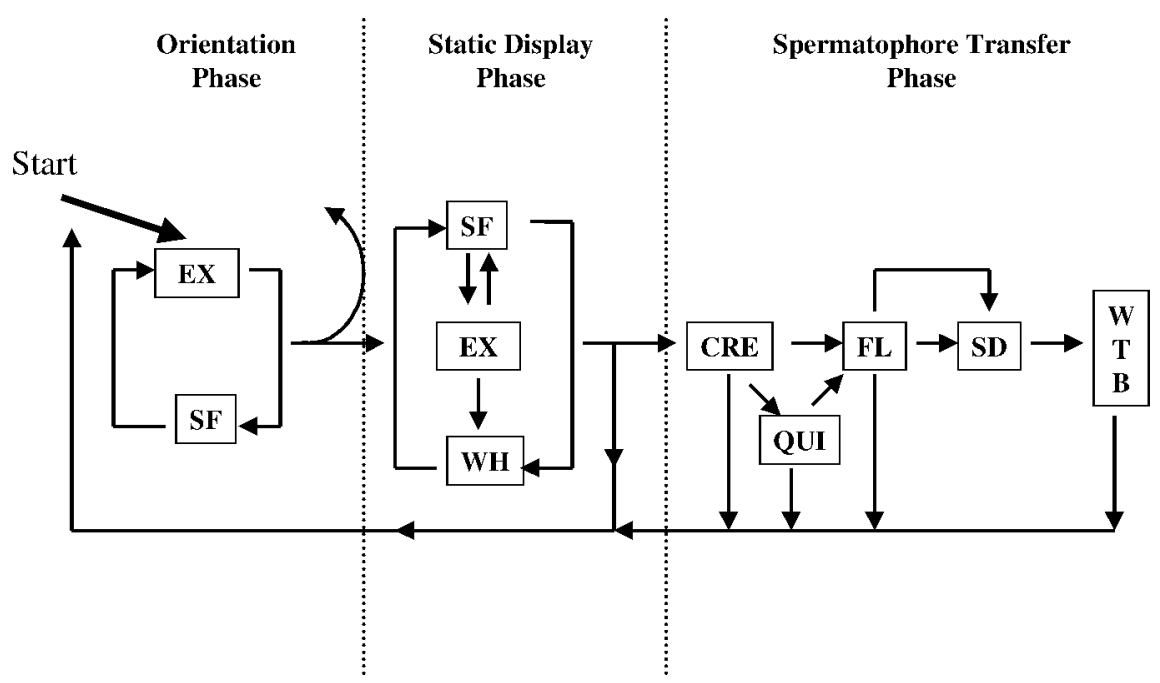

Figure 2. Scheme of male behaviours in the sexual encounter in T. pygmaeus. Only the most frequent transitions are shown through arrows. (EX: exhibition; SF: Slow fan; WH: whip; CRE: Creep; QUI: Quiver; FL: Flamenco; SD: Spermatophore deposition; WTB: Wiggle tail bent).

only (19\%). If the female follows the male in creep, he stops and starts quiver, usually continuing with flamenco (fig. 2). The females appear to be attracted by the moving tip of the male's tail and approach, sometimes touching the base of the tail. The male then jumps ahead, deposits the spermatophore and continues with wiggle tail bent (fig. 2). Once again, the female seems to be attracted by the moving tail and pick up by stepping forwards to touch the flank of the male with her snout. At the same time she passes over the spermatophore which may adhere to her cloaca (or sometimes to another part of her body). Spermatophore deposition only occurred in six courtships, in two cases after tail touch, and only in one of these the spermatophore was picked up.

Total courtship duration ranged from $124.5 \mathrm{~s}$ to $11174 \mathrm{~s}$ ( $2653.1 \mathrm{~s}$ on average), but only an average of $2203.6 \mathrm{~s}(81.40 \%)$ of this time included male display (table 1). In courtships which reached the Spermatophore Transfer phase, those including spermatophore deposition were also significantly longer than those which did not include this pattern $\left(F_{1,20}=4.69, P=0.042\right.$ : Mean duration of courtships with Spermatophore Transfer phase $=4301 \mathrm{~s}(s=3600, n=13)$; Mean duration in courtships including spermatophore deposition $=5115.7(s=3557.4, n=6))$. After the female was introduced into the aquarium, the time to the initiation of courtship by the male was extremely variable (on average 714.4 s). Some males started to court immediately the female was introduced, others did not start for 48 minutes (table 1).

Behaviours characterised by the longest bouts were those with worm-like tail movements (flamenco, wiggle tail bent and quiver). Bouts of exhibition also lasted a considerable time (average $64.4 \mathrm{~s}$ ). Other frequent behaviours (whip and slow fan), were performed 
Table 1. Mean time (in seconds) per courtship of single bouts of sexual behaviours ( $n=$ number of courtships) of male T. pygmaeus. Starting time is the time interval from female introduction to the moment when the male started to court. \%beh/dur is the percentage of the time of males performing courtship behaviours over the total courtship duration.

\begin{tabular}{|c|c|c|c|c|c|}
\hline Behaviours & mean & $s$ & $\min$ & $\max$ & $n$ \\
\hline Exhibition & 64.4 & 32.8 & 17.2 & 158.9 & 32 \\
\hline Slow fan & 6.5 & 2.7 & 2.0 & 12.7 & 26 \\
\hline Whip & 2.3 & 2.0 & .5 & 6.6 & 15 \\
\hline Sniff & 23.4 & 20.3 & 4.0 & 83.3 & 17 \\
\hline Flamenco & 130.1 & 113.7 & 18.0 & 401.1 & 9 \\
\hline Creep & 18.1 & 19.0 & 4.6 & 69.2 & 12 \\
\hline Quiver & 69.9 & 48.1 & 23.7 & 133.7 & 4 \\
\hline Spermatop. dep & 3.0 & 1.8 & 1.0 & 4.6 & 6 \\
\hline Wiggle tail bent & 180.3 & 98.9 & 31.0 & 295.0 & 6 \\
\hline Courtship & 2653.1 & 2903.9 & 124.5 & 11174.0 & 32 \\
\hline male behaviour & 2203.6 & 2730.9 & 119.9 & 10562.0 & 32 \\
\hline$\%$ beh/dur & 81.4 & 22.1 & 20.0 & 100.0 & 32 \\
\hline Starting time & 714.4 & 818.9 & 0.0 & 2880.0 & 32 \\
\hline
\end{tabular}

in short bouts ( $<7 \mathrm{~s}$ on average). A single slow fan movement was performed at an average rate of 2.21 beats/s $(s=0.37, n$ bouts $=100, n$ males $=10)$, while slow fanning bouts lasted on average $6.57 \mathrm{~s}$ (table 1$)$.

Exhibition, slow fan and whip were the mostly frequently performed behaviours, scoring 44,29 and $14 \%$ respectively of the total number (fig. 3). All other behaviours scored below $6.5 \%$. In contrast, when the duration of each act in relation to the total duration of courtship is considered (fig. 3), exhibition was performed for $83 \%$ of the time invested in courtship, much longer than any other behaviour. Slow fan (the second most frequent behaviour) lasted for approximately $6 \%$ of total courtship time, and whip for less than $1 \%$.

\section{Behaviour transitions}

Courtships mostly began with exhibition, and only occasionally with sniff, whip, slow fan or flamenco. Exhibition was often (48.5\% of cases) followed by slow fan, after which males usually repeated exhibition (71.7\%). Exhibition was also commonly followed by whip $(42.3 \%)$, which usually preceded slow fan (91.3\%). These three behaviours form the basis of courtship behaviour during the orientation and static display. The remaining behaviours were not so frequent. Sniff only occurred after exhibition or slow fan, although one courtship started with it (table 2).

Flamenco was usually performed during the spermatophore transfer phase, but it was occasionally observed during the orientation phase after exhibition (1.1\%), when males tried to attract the attention of unresponsive females. It was even performed as the initial behaviour in the courtship sequence (table 2). 

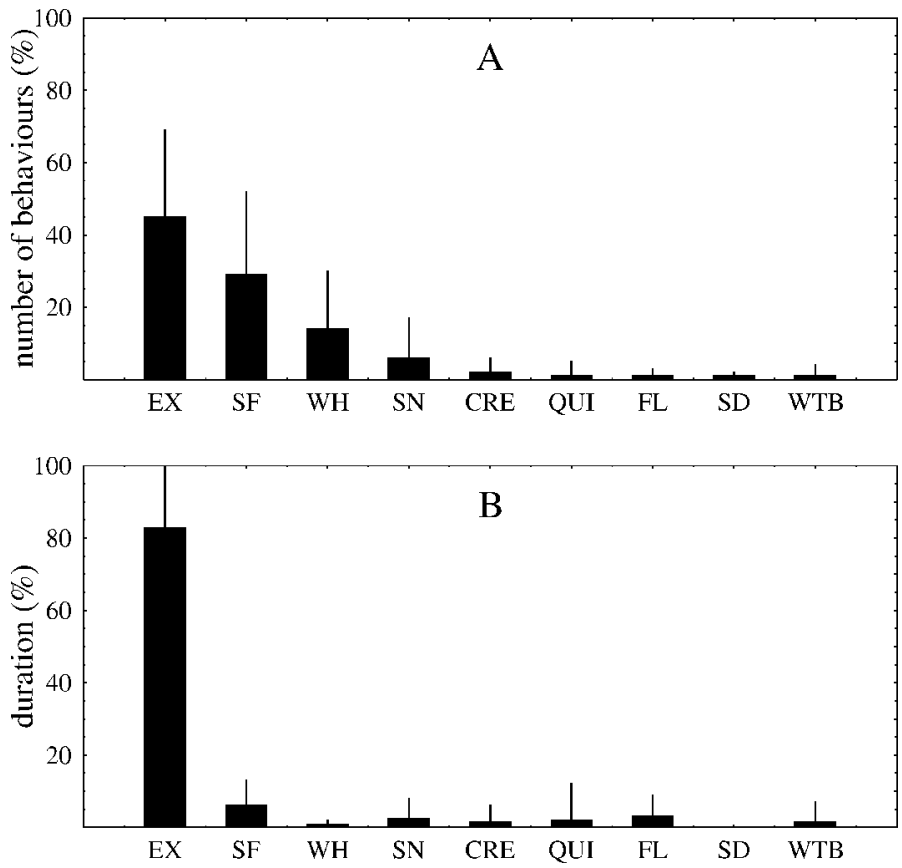

Figure 3. Average (bars) and standard deviation (vertical lines) of the percentage of a) occurrence and of b) the time invested in the different behaviours during the sexual encounters of T. pygmaeus. (EX: exhibition; SF: Slow fan; WH: whip; CRE: Creep; QUI: Quiver; FL: Flamenco; SD: Spermatophore deposition; WTB: Wiggle tail bent).

Table 2. First order transitions (\%) matrices in T. pygmaeus courtships.

$1^{\text {st }}$ behaviour $\quad n$ Exhibition Slow fan Whip Sniff Flamenco Creep Quiver Spermatophore Wiggle tail deposition bent

\begin{tabular}{lcccccccccc}
\hline Exhibition & 478 & - & 48.5 & 42.3 & 5.2 & 1.1 & 4.0 & 0 & 0 & 0 \\
Slow Fan & 590 & 71.7 & - & 27.0 & 1.2 & 1.5 & 0 & 0 & 0 & 0 \\
Whip & 369 & 6.0 & 91.3 & - & 0 & 0 & 2.7 & 0 & 0 & 0 \\
Sniff & 34 & 76.5 & 17.7 & 2.9 & - & 0 & 2.9 & 0 & 0 & 0 \\
Flamenco & 28 & 71.4 & 14.3 & 0 & 0 & - & 0 & 0 & 14.3 & 0 \\
Creep & 36 & 27.7 & 0 & 0 & 0 & 41.7 & - & 30.6 & 0 & 0 \\
Quiver & 12 & 33.3 & 0 & 0 & 0 & 33.3 & 16.7 & - & 16.7 & 0 \\
Deposition & 5 & 0 & 0 & 0 & 0 & 0 & 0 & 0 & - & 100.0 \\
Wiggle Tail Bent & 5 & 40.0 & 60.0 & 0 & 0 & 0 & 0 & 0 & 0 & - \\
Start & 32 & 87.5 & 3.1 & 3.1 & 3.1 & 3.1 & 0 & 0 & 0 & 0 \\
\hline
\end{tabular}

The third phase started with creep. If the male continued with the spermatophore transfer phase, creep was usually followed by flamenco (41.7\%) or quiver (30.6\%). If, however, the male reverted to the orientation phase, creep was followed by exhibition. Interruption of the spermatophore transfer phase also occurred after flamenco, which would be followed 
by exhibition (71.4\%) or slow fan (14.3\%). Quiver was mostly performed between creep and flamenco, but occasionally it was followed by exhibition (interrupting the deposition phase), or led directly to spermatophore deposition. Spermatophore deposition occurred four times after flamenco and twice following quiver. Males always performed wiggle tail bent after deposition, indicating the position of the spermatophore to the female. Display would then begin again with exhibition (40\%) or slow fan (60\%) (table 2).

\section{Discussion}

Males of Triturus pygmaeus differ in their courtships from other Triturus species, even from T. marmoratus. In all Triturus species, males exhibit an elaborate sexual display in order to ensure the receptivity of females before depositing spermatophores. The description of courtship behaviour is very precise in some studies, while other behaviours are described in more ambiguous terms. For example, Arntzen and Sparreboom (1989) do not consider that male T. cristatus perform fan behaviour, whereas Green (1989) considers that the regular tail beating of $T$. cristatus males is sufficiently similar to fan as described for T. vulgaris (Halliday, 1974) for the same term to be applied. Sparreboom and Teunis (1990) classified the same tail movements as rocking. Small newts fan with the tail almost parallel with the flank (Halliday, 1974, 1977; Pecio and Rafiński, 1985; Giacoma and Sparreboom, 1987; Rafiński and Pecio, 1992; Faria, 1993) and sustain a very rapid beating of the tail tip; 8 to 15 beats/s in T. boscai (Faria, 1993), 6.3 beats/s in T. montandoni (Pecio and Rafiński, 1985). This produces a current of water that probably directs odour towards the female (Halliday, 1974). In contrast, $T$. cristatus males perform regular tail beats ( 0.5 to 0.8 beats/s) by opening the angle from the flank to a position in which the tail is only slightly flexed (Green, 1989). The predominant tail movements observed in T. pygmaeus are slower than fan in small newts and faster than the tail movements of T. cristatus. The angle formed between the flexed tail and the flank is also much greater than that seen in other species. Triturus pygmaeus males thus clearly exhibit their flanks to the females, probably transmitting visual signals to the females, sometimes even performing these movements from a considerable distance. The fanning tail movement in T. pygmaeus has more in common with that of T. cristatus than the smaller Triturus species, but in order to make the differences clear, we have applied the new term slow fan.

Another unique part of sexual display in T. pygmaeus is exhibition, the alert or ready posture that plays an important part in the orientation and static display phases. There is no exact equivalent behaviour described in the other species, although a similar alert behaviour, also known as exhibition, was described for T. marmoratus (Sparreboom and Teunis, 1990). In small newts, an initial posture of the male with the head pointing towards the female has been reported at the very beginning of courtship (Pecio and Rafiński, 1985; Rafiński and Pecio, 1992). In T. vulgaris, a ready posture was described, while moving-tothe-front (Halliday, 1974), and in T. cristatus a ready posture or cat-buckle was described as 
a characteristic courtship behaviour alternating with other male movements (Green, 1989; Sparreboom and Teunis, 1990; Zuiderwijk, 1990). The scoring of this alertness posture in T. cristatus and T. marmoratus (Sparreboom and Teunis, 1990), was higher than any other behaviour, revealing its importance in courtship. However, in most descriptions of Triturus sexual behaviour, these actions are not quantified, or are poorly considered. Sparreboom and Teunis (1990) described exhibition in T. marmoratus as an alertness posture of males with forelegs stretched. Males in aggressive male-male interactions frequently use this posture (Zuiderwijk, 1990).

In T. pygmaeus, exhibition was the most frequently recorded behaviour during a sexual encounter. The male is displaying his colours along the flank, crest and tail to the female and we suggest this behaviour may constitute an important visual component of courtship.

Another prominent behaviour pattern in T. pygmaeus is flamenco. This movement was described for T. italicus and T. boscai as a characteristic behaviour in courtship (Giacoma and Sparreboom, 1987; Rafiński and Pecio, 1992; Faria, 1993), and appeared to function as a bait-mimic, in order to attract unresponsive females (Giacoma and Sparreboom, 1987). A similar behaviour, distal lure, was described for T. alpestris as a behaviour wich strongly attracts females (Denoël et al., 2001). In our population of pygmy newts, flamenco was mostly associated with unresponsive females, and it was included in the spermatophore transfer phase, probably in order to ensure the responsiveness of the female before deposition. However, it has been also observed during the orientation or static display phases, when this behaviourmay allow males to attract unresponsive females using less energy investment than that required by the more vigorous courtship behaviours. In T. alpestris, distal lure is also included in the Spermatophore transfer phase, although it is considered less efficient than other waiting tactics (Denoël et al., 2001).

The sexual behaviourof T. marmoratus has only been described in detail for a population from northern France (Sparreboom and Teunis, 1990; Zuiderwijk, 1990), in which male courtship behaviour consisted primarily of cat-buckle, lean-in and tail lashes. Courtship behaviour was considered similar to that of T. cristatus (Green, 1989; Zuiderwijk, 1990) although with a lower frequency of rocking behaviour (Sparreboom and Teunis, 1990). Sexual behaviour in our population of $T$. pygmaeus differed in several ways: rocking was not observed, but stationary males simply moved the flexed tail in a slow fanning. The frequent and powerful tail lashes in T. marmoratus usually touched the female's head or body (Zuiderwijk, 1990), while whip in T. pygmaeus was less vigorous and never touched the female, as described for T. vulgaris (Halliday, 1974, 1977) and T. montandoni (Pecio and Rafiński, 1985; Michalak, 1996). The males of T. marmoratus elevate the body and lean over the female during tail lash and lean-in (Zuiderwijk, 1990). Similarly, in the males of $T$. cristatus while rocking, the crest moves towards the flank, functioning as a groove which channels water from the beating tail to the head of the females, enhancing olfactory stimulation (Green, 1989). Such inclination of the crest is not observed in pygmy newts, which have a much lower crest. In T. marmoratus, sniff was more frequent than rocking or tail lash (Sparreboom and Teunis, 1990), whereas in T. pygmaeus sniffing is 
rare. Thus while the display in T. marmoratus contains a significant amount of physical contact between males and females, such contact in T. pygmaeus is limited to occasional sniffing. Push-back is another tactile movement observed in several species of the genus but this behaviour was not observed in T. pygmaeus. It is absent from courtship display in T. cristatus (Arntzen and Sparreboom, 1989; Green, 1989), and only occasional pushbacks to the female were reported in T. marmoratus (Sparreboom and Teunis, 1990). In other species of Triturus, courtship encounters start after approaching and sniffing of both partnerts (Halliday, 1974; Pecio and Rafiński, 1985; Giacoma and Sparreboom, 1987; Green, 1989; Zuiderwijk, 1990; Rafiński and Pecio, 1992; Faria, 1993); pygmy newts, however, frequently start with males in exhibition, standing or moving around the female, but not approaching her.

The lack of physical contact, and the fact that the distance between males and females during courtship is highly variable, suggests that visual signals may be of primary important in the sexual display of T. pygmaeus. Although slow fan and whip in T. pygmaeus, probably send chemical signals to females they are not performed as close to the females as in other Triturus species.

Despite differences in courtship behaviour between T. pygmaeus and T. marmoratus, sexual behaviour in $T$. pygmaeus may be classified with that in the group of large, high crested newts. The group (T. cristatus, T. carnifex, T. karelinii, T. dobrogicus, T. marmoratus and T. vittatus) is characterized by highly decorated males, display that is essentially static and lacks the rapid fanning of small newts and no retreat display (Halliday, 1990). The main differences in the courtship behaviour of T. pygmaeus described in this study are probably associated with the reduction in crest and body size. In addition the short activity season and occasional low responsiveness of females may have influenced the introduction of alternative behaviours (such as flamenco) never observed in T. marmoratus.

Acknowledgements. We thank A. Escacena, P. Chacón, A. Conejo, R. Gavira, M.C. Estévez, P. Rubio, I.G. Mestre, R. Reques and M.J. Borrego for field assistance. Dr Juliet Kauffman kindly checked and reviewed a previous version of the manuscript, Dr A. Green and Dr E. Aguilera also commented an earlier version. J. LópezRojas drew figure 1. The comments of reviewers, especially Dr M. Sparreboom, contributed to improve the manuscript.

\section{References}

Arntzen, J.W., Sparreboom, M. (1989): A phylogeny for the old world newts, genus Triturus. Biochemical and behavioural data. J. Zool., London 219: 645-664.

Denoël, M., Poncin, P., Ruwet, J.-C. (2001): Alternative mating tactics in the Alpine newt Triturus alpestris alpestris. J. Herpetol 35: 62-67.

Díaz-Paniagua, C. (1998): Reproductive dynamics of a population of small marbled newts (Triturus marmoratus pygmaeus) in south-western Spain. Herpetol. J. 8: 93-98.

Díaz-Paniagua, C., Mateo, J.A., Andreu, A.C. (1996): Age and size structure of populations of small marbled newts (Triturus marmoratus pygmaeus) from Doñana National Park (SW Spain). A case of dwarfism among dwarfs. J. Zool., London 239: 83-92. 
Faria, M.M. (1993): Sexual behaviour of Bosca's newt, Triturus boscai. Amphibia-Reptilia 14: 169-185.

García-París, M., Arano, B., Herrero, P. (2001): Molecular characterization of the contact zone between Triturus pygmaeus and T. marmoratus (Caudata, Salamandridae) in central Spain and their taxonomic assessment. Rev. Esp. Herp. 15: 115-126.

García-París, M., Herrero, P., Martín, C., Dorda, J., Esteban, M., Arano, B. (1993): Morphological characterization, cytogenetic analysis, and geographical distribution of the pygmy marbled newt Triturus marmoratus pygmaeus (Wolterstorff, 1905) (Caudata, Salamandridae). Bijdr. Dierk. 63: 3-14.

Giacoma, C., Balletto, E. (1988): Phylogeny of the salamandrid genus Triturus. Boll. Zool. 55: 337-360.

Giacoma, C., Sparreboom, M. (1987): On the sexual behaviour of the Italian newt, Triturus italicus (Caudata, Salamandridae). Bijdr. Dierk. 57: 19-30.

Green, A.J. (1989): The sexual behaviour of the great crested newt, Triturus cristatus (Amphibia, Salamandridae). Ethology 83: 129-153.

Griffiths, R.A. (1996): Newts and Salamanders of Europe. London, Poyser.

Halliday, T.R. (1974): Sexual behaviour of the smooth newt, Triturus vulgaris (Urodela, Salamandridae). J. Herpetol. 8: 277-292.

Halliday, T.R. (1975): An observational and experimental study of sexual behaviour of the smooth newt, Triturus vulgaris (Amphibia, Salamandridae). Anim. Behav. 23: 291-322.

Halliday, T.R. (1977): The courtship of European newts. An evolutionary perspective. In: The Reproductive Biology of Amphibians, p. 185-232. Taylor, D.H., Guttman, S.I., Eds, New York, Plenum Press.

Halliday, T.R. (1990): The evolution of courtship behavior in newts and salamanders. Advances in the Study of Behavior 19: 137-169.

Himstedt, W. (1979): The significance of color signals in partner recognition of the newt Triturus alpestris. Copeia 1979: 40-43.

Michalak, P. (1996): Repeatability of mating behaviour in Montandon's newt, Triturus montandoni (Caudata, Salamandridae). Ethology, Ecology \& Evolution 8: 19-27.

Pecio, A., Rafiński, J. (1985): Sexual behaviour of the Montandon's newt, Triturus montandoni (Boulenger) (Caudata, Salamandridae). Amphibia-Reptilia 6: 11-22.

Rafiński, J., Pecio, A. (1992): The courtship behavior of the Bosca's newt, Triturus boscai (Amphibia, Salamandridae). Folia Biologica (Kraków) 40: 155-165.

Sparreboom, M., Teunis, B. (1990): The courtship display of the marbled newt, Triturus marmoratus marmoratus. Amphibia-Reptilia 11: 351-361.

Zuiderwijk, A. (1990): Sexual strategies in the newts Triturus cristatus and Triturus marmoratus. Bijdr. Dierk. 60: $51-64$.

Received: January 17, 2002. Accepted: May 10, 2002. 